УДК 332.1. 338.2.

DOI 10.35433/ISSN2410-3748-2019-1(24)-4

І.О. Клімова, к.е.н., старший викладач кафедри економіки, менеджменту і маркетингу К.М. Кащук, к.е.н., старший викладач кафедри економіки, менеджменту і маркетингу Житомирський державний університет імені Івана Франка

\title{
ЗАРУБІЖНИЙ ДОСВІД СОЦІАЛЬНО-ЕКОНОМІЧНОГО РОЗВИТКУ РЕГІОНІВ ТА МОЖЛИВІСТЬ ЙОГО ВПРОВАДЖЕННЯ В УКРАЇНИ
}

Проблема аналізу сочіально-економічного розвитку регіонів постійно знаходиться в центрі уваги теорії і практики регіонального управління. Однак, у сучасних кризових умовах вона набула особливої значимості, оскільки кризові умови господарювання вимагають формування ефективних і дієвих механізмів управління складними територіальними системами, які б, базуючись на новітніх наукових досягненнях, дозволяли ефективно вирішувати актуальні проблеми подолання кризи з мінімальними негативними соціальними та економічними наслідками, а також сприяли попередженню виникнення кризи.

Ключові слова: регіон; сочіально-економічний розвиток; регіональний розвиток; економічний розвиток; економічна політика; державне управління

\section{INTERNATIONAL EXPERIENCE OF REGIONS' SOCIO-ECONOMIC DEVELOPMENT AND POSSIBILITY OF ITS IMPLEMENTATION IN UKRAINE}

Problem of the regions socio-economic development analysis is constantly in the focus of theory and practice of regional management. However, in the today's crisis conditions it has become particularly important as the crisis economic conditions require the development of effective and

efficient mechanisms for managing complex territorial systems, which, based on the latest scientific advances, allow to solve effectively the actual problems of overcoming the crisis with minimal negative social and economic consequences, and also contributed preventing a crisis.

Keywords: region; socio-economic development; regional development; economic development; economic policy; governance.

Постановка проблеми. Виникнення проблем регіонального розвитку зумовлено індивідуальними особливостями регіонів, до яких можна віднести: тенденції розвитку регіону в даний час; різноманітність історичних, природних, соціально-економічних, політичних факторів; господарську

(С) Клімова I.О., Кащук К.М. 
спеціалізацію; комплексність і перспективність розвитку, його конкурентні переваги; місце і значення регіону в системі територіального поділу праці, інтеграційних процесах i т.д. [1, c.84]. Їх особливості визначають використання певного набору інструментів та стимулів, за допомогою яких, як показує досвід розвинених країн світу, в умовах передачі низки повноважень місцевим органам влади та управління реалізується наближення послуг адміністративного та суспільного характеру до населення, підсилюється спроможність територіальних громад до вирішення місцевих проблем власними силами.

Тому в контексті євроінтеграційних процесів одним 3 найважливіших напрямів вирішення вказаної проблеми $є$ формування ефективної регіональної політики через вдосконалення стимулювання соціальноекономічного розвитку регіонів в умовах зміни формату управління територіальними громадами.

Мета статті полягає у вивченні зарубіжного досвіду щодо основних показників соціально-економічного розвитку регіонів та можливості його застосування в українських реаліях.

Аналіз останніх досліджень та публікацій. Проблеми регіонального розвитку, а саме ті, що пов’язані з розробкою моделей комплексної його оцінки, розглядали в своїх наукових працях такі вчених як I.С. Благун, 3.С. Варналій, В.М. Геєць, Л.С. Гур’янова, Б.М. Данилишин, Л.І. Дмитришин, М.І. Долішній, Ю.В. Донченко, С.М. Злупко, М.О. Кизим, Т.С. Клебанова, О.М. Нижник, О.І. Омельченко, В.С. Пономаренко, Н.С. Різник, В.П. Семиноженко та ін., а також в працях зарубіжних науковців: А. Алчиан, Р. Барро, Т. Веблен, Р. Коуз, Д. Ромер, Кс. Сала-і-Мартін, Р. Солоу.

Однак, ціла низка питань, які пов’язані територіальними відмінностями у соціально-економічному розвитку регіонів, а також 3 методичним забезпеченням процесу формування рейтингових оцінок при реалізації різних функцій управління соціально-економічним розвитком регіонів, розробки 
ефективних механізмів управління не знайшли належного відображення в наукових дослідженнях.

Виклад основного матеріалу. На світовому рівні концепції політики регіонального розвитку за останні 20 років змінили акцент на «регіон» як на активний елемент процесу розвитку, на відміну від концепції регіону виключно як одержувача державної допомоги. У цьому плані для України корисним може бути досвід реалізації політики регіонального розвитку, насамперед, у країнах Західної Європи, членів СС [2].

На рубежі століть ЄС перетворився, по-суті в «Європу регіонів», «Союз регіонів», в якому розробляється і активно проводиться конструктивна регіональна політика. Вона здійснюється шляхом скорочення розриву в рівнях розвитку між окремими територіями, аграрної інтеграції, регулювання підприємницької діяльності тощо. Так, зменшення розриву між різними регіонами спільноти та ліквідація відставання в розвитку найменш розвинених регіонів були однією з проголошених цілей Римського договору 1957 p. [2].

Iз часу підписання Римського договору $Є \mathrm{C}$ прагне скоротити регіональну нерівність. Ця мета підтверджена в Договорі про утворення Європейського Союзу, підписаному в Маастрихті в 1991 р., полягає у зменшенні нерівності в рівнях розвитку найбільш розвинених і найбільш відсталих регіонів. У країнах $Є С$ представлені практично всі типи проблемних територій і всі вони тією чи іншою мірою підпадають під сферу діяльності політики регіонального розвитку. Якщо першими об'єктами політики були депресивні території, які спеціалізувались на видобутку вугілля, чорній металургії, окремих галузях важкого машинобудування, текстильній промисловості, то, починаючи 3 60-х років минулого століття, виділяються депресивні та слаборозвинуті регіони.

Першою європейською країною, яка зіштовхнулась 3 проблемою структурно кризових територій, була Великобританія. До таких регіонів були 
віднесені Уельс, Шотландія, Північний Схід та Північна Ірландія. Більшість 3 них були старими промисловими районами 3 вузькою спеціалізацією в добувній і переробній промисловості. Перший у світі закон, який регулював безпосередньо розвиток регіонів (так званих «спеціальних зон»), прийнято у 1934 р. саме у Великобританії [3].

У Польщі законодавчо виділені території підтримки, які поділено на слабко розвинені і території з найсприятливішими умовами розвитку. В Угорщині території, яким надається підтримка регіонального розвитку, класифіковані на слаборозвинені регіони, що підлягають реструктуризації, переважно сільськогосподарські регіони; прикордонний регіон у несприятливих умовах. Словенія ввела поділ проблемних територій на економічно слабкі області або муніципалітети, область або муніципалітет із структурними проблемами i високим рівнем безробіття, область із обмеженим розвитком і обмеженим потенціалом [4, с. 26].

Уряд Німеччини постійно переглядає вимоги до визнання регіонів проблемними і з 2007 р. скоротила число категорій проблемних регіонів до двох: економічно відсталих (A) і регіонів зі структурними проблемами (C). Виділені також додаткові зони (Д), для яких дозволена лише підтримка інвестицій малого і середнього бізнесу, стимулювання розвитку інфраструктури, а також проекти сприяння кластерам.

Цікавим і корисним для української держави $є$ досвід регіонального розвитку країн, які не входять до Європейської співдружності. Це і США, і країни Латинської Америки, азіатського регіону та країн СНД. Регіональна політика і політика регіонального розвитку поступово займає ключові позиції у соціально-економічному розвитку цих країн $[5$, с. 8].

Відомо, що США як держава об'єднує 50 штатів і федеральний округ Колумбія, у підпорядкуванні знаходяться також ряд островів. Виходячи 3 природних особливостей штатів, у країні не тільки є завжди потенційно слабкі в економічному розвитку території, але й періодично виникають нові 
проблемні території, як наслідок зміни структури промисловості та впровадження нових технологій чи закриття військових баз і полігонів. Законодавство США визначає не лише типи проблемних територій, якими опікується держава, а й способи державної підтримки їх розвитку (Закон «Про громадські роботи та економічний розвиток» від 1965 р.).

В азіатському регіоні найбільша асиметрія регіонального розвитку спостерігається в Китаї та Індії. Тут, поряд 3 економічно розвиненими регіонами, які демонструють високі темпи росту, де кожні 26 хвилин відкривається нова фабрика 3 іноземними інвестиціями, існують регіони 3 середнім доходом 1 дол. США на день та істотні перекоси в доходах між різними категоріями населення. Так, городяни в Китаї заробляють у 3,5 раза більше, ніж сільські жителі [6, с. 5].

3 точки зору регіональної економічної політики, яка проводиться в Російській Федерації, сьогодні головними типами проблемних регіонів $є$ відсталі (слаборозвинуті), депресивні, кризові, а також прикордонні. Вітчизняні вчені-регіоналісти проблемні території теж поділяють на слаборозвинені та депресивні. Про депресивність територій в Україні почали говорити ще в кінці 90-х років. Депресивними вважаються такі регіони, економічна відсталість яких зумовлена стагнацією, спричинена структурною кризою, що охопила виробництва, які стали неефективними внаслідок зміни умов розвитку [7, с. 93].

Отже, не всі регіони мають однакові економічні і соціальні можливості, які роблять їх привабливими для здійснення господарської діяльності. Якщо порівняти представлену класифікацію депресивних територій у Законі України «Про стимулювання розвитку регіонів» із прийнятою Свропейським Співтовариством, то визначені Законом депресивні території є лише одним видом із типів проблемних територій. Усі показники для визнання регіону чи району депресивним, згідно із зазначеним вище законом, мають бути зібрані протягом останніх трьох років, що в свою чергу, унеможливлює спробу 
регіону отримати такий статус, особливо для сільського. Наприклад, частка зайнятого населення у сільському господарстві за останні вісім років скоротилась у чотири рази, тому жодний сільський регіон, за цим визначенням, не може бути визнаним депресивним [8, с. 167].

Сдині критерії визначення «проблемних» регіонів, запроваджені політикою регіонального розвитку СС (1983р.) (ВВП на душу населення; характер зайнятості; рівень безробіття; динаміка міграційних потоків), є економічними показниками. Однак депресивність регіону в нашій країні потрібно розглядати насамперед як категорію соціальну, а не економічну. Адже головною метою розвитку регіону є досягнення гідного рівня та якості життя населення, що проживає в ньому, яка не оцінюється лише показником валового регіонального продукту. Тому потрібні інноваційні інструменти для вирішення проблем асиметрії розвитку регіонів, подолання депресивності окремих їх територій [9].

Європейська політика регіонального розвитку має три основні спрямування. По-перше, робиться акцент на економічному зближенні регіонів $з$ метою допомогти менш розвиненим регіонам (що розташовані в основному в нових країнах-учасницях) і зменшити їх відставання від більш розвинутих країн.

По-друге, реалізуються широкі заходи, спрямовані на поліпшення регіональної конкурентоспроможності та зайнятості. Третя категорія стратегій спрямована на співпрацю регіонів i країн для послаблення економічного значення національних кордонів [10, с. 18]

Такі країни як Німеччина та Італія приділяють велику увагу питанням регіонального розвитку, визначаючи головну іiі мету - забезпечення можливостей для структурно слабких регіонів брати активну участь у соціально-економічному розвитку країни шляхом мінімізації впливу негативних чинників, пов'язаних з географічним розміщенням цих регіонів. Так, Конституція Німеччини наголошує на необхідності створення однакових 
умов для роботи і життя людей в усіх частинах країни. Конституція Італії наголошує, що держава повинна усувати всі перешкоди до ефективної участі усіх громадян в економічному, соціальному і політичному розвитку країни. Для досягнення поставлених цілей створюються довгострокові та конкурентоспроможні робочі місця, що сприятиме стабілізації ситуації на регіональному ринку праці і полегшити здійснення структурних перетворень [11].

В Ірландії, Греції, Португалії, Іспанії, в яких розташовані найбільш бідні регіони, регіональна політика здійснюється в умовах слабкого розвитку національної економіки порівняно з іншими країнами-членами $\mathrm{CC}$, тобто особлива роль відводиться проблемам національного економічного розвитку, а розвитку проблем регіонів - другорядна [12, с. 15].

У Великобританії традиційно регіональна політика була спрямована на переоріснтацію і перерозподіл надлишкових і мобільних капіталів і робочих місць із районів прискореного розвитку (регіонів-донорів) у депресивні (регіони-реципієнти) як основний механізм стимулювання економічного розвитку депресивних регіонів і подолання регіонального дисбалансу. Низка законодавчих актів, прийнятих у 60-70-ті роки XX ст., істотно розширила стимули для проблемних регіонів, зокрема пільгові субсидії на придбання основних засобів, вільну амортизаційну політику, пряме планування регіонального розвитку тощо [13].

У США пріоритетним напрямком вирівнювання регіональних диспропорцій $є$ фінансова підтримка проблемних регіонів. Найбільш ефективним інструментом виявилося бюджетне фінансування окремих секторів економіки в депресивних регіонах, причому основна частина фінансування $з$ федерального бюджету спрямовувалась на субсидування та кредитування заходів щодо раціонального використання ресурсів і охорони навколишнього середовища, розвитку промисловості i сфери надання податкових та амортизаційних пільг. Керівництво регіональними програмами 
здійснюють не самі регіони, а система спеціальних незалежних установ при федеральному уряді і спеціально створені федерально-штатні органи [14, с. 33].

У Канаді діяльність, спрямовану на вирівнювання рівнів економічного розвитку регіонів, почав здійснювати уряд країни ще на початку 60-х років минулого століття і досі має високий державний пріоритет. Здійснення ii відбувається шляхом прямих фінансових трансфертів у рамках надання допомоги депресивним регіонам (насамперед Атлантичним штатам), а також реалізації цільових державних програм, які передбачали розвиток i удосконалення усіх видів інфраструктури, підтримка приватних інвестицій, надання податкових та інших пільг, субсидування і підтримку місцевого бізнесу [15, с. 141].

Отже, досвід використання методу програмно-цільового планування для забезпечення регіонального розвитку свідчить, що цільові програми можуть слугувати ефективним інструментом реалізації стратегічних завдань територіального розвитку, якщо потрібно сконцентрувати ресурси для досягнення конкретних цілей. Однак, цей підхід має свої недоліки, пов'язані 3 недоліками організаційно-методичного механізму здійснення цільових програм, тобто їх формуванням, реалізацією і способами контролю.

Досвід реалізації регіональної політики в Китаї засвідчив, що на першому етапі іï здійснення відбулась пріоритетна підтримка регіонів, що мають найбільш високий економічний та інвестиційний потенціал. Це i створення вільних економічних зон та технопарків 3 ліберальним режимом зовнішньої торгівлі, сприятливими умовами господарювання, випереджаючим розвитком у вибраних регіонах елементів інфраструктури всіх видів (перш за все, ринкової та інвестиційної), наданням податкових та інших пільг. Східний регіон, що включає приморські провінції та провінції, наближені до адміністративних i економічних центрів країни, виступив локомотивом здійснення регіональної політики, і розвиток його увійшов до 
історії як «китайське чудо». Проте здійснювана Китаєм державна регіональна політика викликала і серйозні диспропорції у розвитку між Східним регіоном та внутрішніми провінціями країни, які можуть бути зменшені тільки шляхом корекції державної регіональної політики країни на користь відстаючих регіонів [16, с. 10].

У 2016 році за обсягом номінального ВВП Китай посів друге місце у світі, випередивши Японію, яка за даними МВФ перебувала на другому місці з 1968 році. Таким чином, економіки двох країн регіону, КНР та Японії, обіймають відповідно друге та третє місце у світі. Ще один вагомий гравець регіону - Індія -, за цим показником посідає 7 місце. Водночас, при розрахунку ВВП на основі методики паритету купівельної спроможності ВВП КНР, Індії та Японії займають відповідно друге, третє і четверте місця у світі, Південної Кореї - 12, Індонезії - 16 [13].

Таким чином, використання в ролі «локомотиву» розвитку економіки країни окремих регіонів, має спочатку певну інвестиційну привабливість, що у багато разів збільшується шляхом здійснення спеціальних державних заходів, зокрема і завдяки зниженню інвестиційної привабливості інших регіонів. Проте ефективні такі заходи лише на початковій стадії модернізації економіки, що має на меті запуск механізму розширеного економічного відтворення в умовах ринкових відносин. Надалі потрібне надання серйозної державної підтримки відсталим регіонам 3 метою вирівнювання соціальноекономічного розвитку різних регіонів країни і уникнення економічного застою та соціальної напруженості.

Сьогодні українські регіони мають різний рівень соціальноекономічного розвитку, про що свідчить наявність більше двох третин проблемних регіонів, значні міжрегіональні диспропорції у рівнях виробництва та добробуту населення. Офіційна статистика показує, що диспропорції між регіонами почали поглиблюватись ще 3 середини 90-х років минулого століття. Головним центром економічного зростання в 
Україні є столиця. Східні регіоні, що орієнтовані на важку промисловість, мають значно кращі економічні результати, ніж регіони на заході України 3 найнижчим показником ВВП на душу населення [17, с. 158].

Значні диспропорції в економічному розвитку регіонів України спричинені існуючими тривалий час недоліками у ключових факторах конкурентоздатності: поганому стані інфраструктури, низькому рівні пристосування до ринкових умов робочої сили, недостатньої підтримки бізнесу, відсутності адекватної інноваційної спроможності підприємств, деградуючому навколишньому середовищі та, як наслідок, низької інвестиційної привабливості територій [14].

Стосовно регіонального аспекту розробки галузевих політик уряду, то, безперечно, основою розвитку регіонів повинно бути ефективне функціонування усіх галузей економіки, які розміщені на його території. Проте необхідно головну увагу зосередити на розвитку підприємств, які $є$ прибутковими для даної території, що буде служити фактором підвищення рівня розвитку регіону. Така політика повинна бути відображена у цільових програмах, стратегіях та концепції соціально-економічного розвитку регіонів і здійснюватись у тісній координації дій державних, регіональних і галузевих органів управління [18, с. 34$]$.

Яскравим прикладом розробки галузевих політик у розрізі регіонів $є$ Японія, яка територіально розділена на економічні райони. При невеликій за розмірами території як країни, так і самих районів, у Японії розроблені і реалізуються на практиці програми зі спеціалізації промисловості розвитку виробничої інфраструктури всередині кожного регіону. Така політика регіоналізації (районування) Японії визначає соціально-економічний розвиток країни загалом, зокрема слугує основою для розробки довгострокових планів комплексного розвитку територій; визначає фінансову, насамперед, податкову, систему, що забезпечує самофінансування територій; сприяє вирішенню соціальних проблем населення шляхом 
економічного регулювання розселення і міграції населення, використовуючи кредити, пільгове оподаткування та інші економічні важелі [19, с. 140].

Інтеграційний напрямок регіональної політики передбачає інтеграцію знизу, що здійснюється за ініціативою органів управління регіонів, та інтеграцію зверху, що здійснюється урядом країни. Так, у Швеції запроваджено державну регіональну політику, спрямовану на формування міцного підгрунтя самостійного розвитку регіонів, насамперед - на основі їх переваг i власного економічного потенціалу. Безперечно, що головними інструментами зазначеної політики є вирівнювання доходів і витрат регіонів, надання їм дотацій, а також участь держави у фінансуванні інвестиційних проектів, що сприяють зміцненню конкурентоспроможності регіонів як на внутрішньому, так і на зовнішніх ринках. Однак треба мати на увазі, що головною передумовою ефективності шведської моделі регіонального розвитку є високий рівень децентралізації державної влади та відповідно автономності і фінансової самостійності органів місцевого самоврядування $[20$, c. 348$]$.

Для України збільшення економічної самостійності регіонів продиктоване необхідністю врахування сучасних загальносвітових тенденцій розвитку, серед яких економічна взаємодія регіонів $\epsilon$ пріоритетним напрямком. Однак влада залишається жорстко централізованою, а повноваження та ресурси місцевого самоврядування - обмеженими та недостатніми [4].

Отже, політика регіонального розвитку в розвинених країнах і країнах, що розвиваються, принципово різна. У країнах, що розвиваються, підтримка надається найбільш перспективним територіям, це веде до зростання регіональної нерівності, але штовхає вперед всю країну. Після досягнення певного рубежу (10-15 тис. дол. ВВП за ПКС на душу населення), відбувається перехід до політики вирівнювання між регіонами. Але в розвинених країнах ефективність такої політики дуже обмежена, хоча i 
спирається вона не тільки на перерозподіл ресурсів, а й на активізацію внутрішніх можливостей розвитку відсталих регіонів, мобілізацію людського капіталу і потенціалу місця.

Історичний досвід регіонального розвитку в інших країнах, особливо в Європі, показує, що важливо ретельно збалансувати мету зменшення диспропорцій із зусиллями, які докладаються для підтримування динамічного економічного зростання. Свросоюз країнам-кандидатам у співтовариство встановлює, що країни повинні мати регіональні інститути, які мають право формулювати цілі регіональної політики, і виступає за координацію регіональної політики між центральним урядом і регіональними органами влади. Так, у Польщі інституціями, які займаються питаннями регіонального розвитку, є Державна рада з питань регіональної політики, Польське агентство з питань регіонального розвитку; у Чехї - Міністерство регіонального розвитку, Міністерство праці та соціальної політики; в Угорщині - Міністерство довкілля і регіональної політики, Національна Рада регіонального розвитку, Національний фонд регіонального розвитку; у Словенії - Фонд регіонального розвитку та збереження заселення сільських районів.

Потрібно зазначити, що в Україні сформувалися компетентне експертне співтовариство, серйозні аналітичні центри, які працюють переважно поза державною сферою. На жаль, їхні розробки та рекомендації у більшості випадків не враховуються органами державної влади, особливо на регіональному рівні. Механізм взаємодії між неурядовим сектором і владою належною мірою не налагоджений.

Світовий досвід державного регулювання регіонального розвитку значною мірою диференційований, що зумовлено особливостями i розвиненістю національних економік, державним устроєм країн, політичними традиціями і формами міжнародної інтеграції, а отже, виділити 
домінуючу модель реалізації політики регіонального розвитку практично неможливо [21, с. 75].

Завдання подолання диспропорцій у соціально-економічному розвитку регіонів країни, що є основним у регіональній політиці урядів розвинених держав, вирішується переважно за рахунок випереджального росту декількох регіонів, що стають центрами інноваційного розвитку країни і демонструють новий тип економічного та соціального зростання для інших територій. Державна підтримка відсталих, слаборозвинених регіонів у вигляді прямих фінансових трансфертів спрямована на вирівнювання соціальноекономічного розвитку різних регіонів країни та уникнення економічного застою та соціальної напруженості.

Висновки. Отже, українська держава, маючи значну кількість регіонів, що претендують на статус депресивних, не здатна одноосібно здійснювати довгострокові інвестиції у такі регіони. Потрібне спрямування інвестиційної співучасті держави, місцевого самоврядування, суб'єктів підприємництва та представників населення, насамперед, на максимально ефективне використання ресурсів регіону. При цьому важливо збалансувати мету зменшення диспропорцій із зусиллями, які докладаються для підтримки динамічного економічного зростання.

\section{1. Список використаних джерел:}

2. Артеменко В. Б. Комплексне оцінювання ефективності соціальноекономічного розвитку регіонів на основі критеріїв якості життя населення / В. Б. Артеменко // Регіональна економіка. - 2015. - № 3. - С.84 93.

3. Сайт Європейської комісії [Електронний ресурс]. - Режим доступу:

http://epp.eurostat.ec.europa.eu/portal/page/portal/nuts_nomenclature/introduction 
4. Міценко Н.Г. Конкурентоспроможність і конкурентні переваги підприємства в сучасних ринкових умовах. - Науковий вісник НЛТУ України. - 2009. - Вип. 19.3

5. Желюк Т. Моделювання динаміки соціально-економічного розвитку [Електронний ресурс] / T. Желюк // Вісник Тернопільського національного економічного університету. - 2017. - № 1. - Режим доступу: http://www.nbuv.gov.ua/portal/Soc_Gum/Vtneu/2017_1/pdf/Zhelyuk\%20T.pdf.

6. Данилишин Б.М. Децентралізація у країнах СС: уроки для України / Б.М. Данилишин, В.В. Пилипів // Регіональна економіка. - 2016. № 1. - C. 5-11.

7. Азарян О. М. Прогнозування та макроекономічне планування в системі державного управління національною економікою: теорія і практика [Текст] : монографія / О. М. Азарян, О. О. Шепелев ; під ред. д-ра екон. наук., проф. О. О. Шубіна ; Донец. нац. ун-т економіки і торгівлі ім. М. ТуганБарановського, Каф. маркетингу і комерц. справи. - Донецьк : [ДонНУЕТ], 2010. - $148 \mathrm{c}$

8. Берегой Т.А. Інституційна структура реалізації регіональної політики у країнах Центральної та Східної Свропи / Т.А. Берегой // Теорія та практика державного управління. - 2012.- Вип. 4 (39). - Суми. 460-467.

9. Державні цільові програми та упорядкування програмного процесу в бюджетній сфері / За ред. В. М. Гейця. - К. : Наукова думка, 2016. $-383 \mathrm{c}$.

10. Бабаєв В. М. Сучасні політичні практики країн Європи: досвід для формування регіональної політики в Україні / В. М. Бабаєв // Державне будівництво - 2017. - № 1, ч. 1 [Електронний ресурс]. - Режим доступу : kbuapa.kharkov.ua/e-book/ db/2017-1-1/doc/5/01.pdf

11. Європейські принципи державного управління; пер. 3 англ. О.Ю. Куленкової. - К.: Вид-во УАДУ, 2016. - 52 с. 
12. Карпець С.Л. Світовий досвід управління регіональним розвитком / С.Л. Карпець // Вісник ЖДТУ. - 2008. - № 2 (44). - С. 252-258.

13. Зульфугарова С. О.Моделі управління економічним розвитком регіону : автореф. дис. канд. екон. наук : 08.00.11 / С. О. Зульфугарова. Запоріжжя, Класич. приват. ун-т. - 2015. - 20 с.

14. Менеджмент європейської економічної інтеграції / під за ред. С. Писаренко. - К. : Знання, 2016. - 373 с.

15. Пруднікова Л.О. Досвід подолання соціально-економічних диспропорцій розвитку регіонів зарубіжних країн / Л.О. Пруднікова // Економічний вісник Донбасу. - 2016. - № 3(21). - С. 32-35.

16. Юрманова Е. А. Государство благосостояния и сектор социальной экономики: формирование механизма институционального взаимодействия / Е. А. Юрманова // Научные труды ДНТУ. Серия: экономическая. Выпуск 40-2. - Донецк: ДонНТУ, 2016 - С. 205 - 212.

17. Чухно А. Інституціоналізм: теорія, методологія, значення / А. Чухно // Економіка України. - 2017. - № 7. - С. 4-12.

18. Сментина Н. В. Стратегічне планування соціально-економічного розвитку на мезорівні: теорія, методологія, практика. Одеса : Атлант, 2015. $365 \mathrm{c}$.

19. Пирог О.В. Стратегічні перспективи економічного розвитку національної економіки України / О.В. Пирог // Бізнес-інформ. - 2016. - № 11. - C. 32-34.

20. Мірзодаєва Т. В. Засади вирівнювання територіальних диспропорцій в контексті економічної безпеки регіонів [Текст] / Т. В. Мірзодаєва// Економічний простір. - 2009. - No21. - С. 138-146.

21. Мазур Г. Ф. Принципи прогнозування соціальноекономічного розвитку регіону / Г. Ф. Мазур, Г. О. Коваленко // Менеджмент XXI століття: проблеми і перспективи [колективна монографія]. - Умань : УНУС, 2015. C. $344-347$. 
22. Чужиков В. Чеська модель регіонального розвитку / В. Чужиков // Економіка України. - 2015. - № 7. - С. 72-78.

\section{REFERENCES:}

1. Artemenko, V. B. (2015). Kompleksne otsiniuvannia efektyvnosti sotsial'no-ekonomichnoho rozvytku rehioniv na osnovi kryteriiv yakosti zhyttia naselennia [Complex assessment of the effectiveness of socio-economic development of regions on the basis of living standard]. Rehional'na ekonomika Regional economics, 3, 84-93 [in Ukrainian].

2. Sait Yevropeys'koyi komisiyi [Sayt of European Commission] https://ec.europa.eu/. Retrieved from https://ec.europa.eu/commission/index_en [in English].

3. Mitsenko, N.H. (2009). Konkurentospromozhnist' i konkurentni perevahy pidpryiemstva $\mathrm{v}$ suchasnykh rynkovykh umovakh [Competitiveness and competitive advantages of the enterprise in modern market conditions]. Naukovyi visnyk NLTU Ukrainy - Scientific Bulletin of NLTU of Ukraine, 19.3 [in Ukrainian].

4. Zheliuk, T. (2017). Modeliuvannia dynamiky sotsial'noekonomichnoho rozvytku [Modeling of the dynamics of socio-economic development ] Visnyk Ternopil's'koho natsional'noho ekonomichnoho universytetu - Bulletin of the Ternopil National University of Economics, 1 Retrieved from http://www.nbuv.gov.ua/portal/Soc_Gum/Vtneu/2017_1/pdf/Zhelyuk\%20T.pdf. [in Ukrainian].

5. Danylyshyn, B.M., \& Pylypiv, V.V. (2016). Detsentralizatsiia u krayinakh YES: uroky dlia Ukrayiny [Decentralization in EU countries: Lessons for Ukraine] Rehional'na ekonomika - Regional economics, 1, 5-11 [in Ukrainian].

6. Azarian, O. M., \& Shepelev, O. O. (2010). Prohnozuvannia ta makroekonomichne planuvannia $\mathrm{v}$ systemi derzhavnoho upravlinnia natsional'noiu ekonomikoiu: teoriia i praktyka [Prediction and macroeconomic planning in the 
system of public administration of the national economy: theory and practice ] Donets'k: Donets'kyi natsional'nyi universytet ekonomiky i torhivli [in Ukrainian].

7. Berehoi, T.A. (2012). Instytutsiina struktura realizatsii rehional'noi polityky u krainakh Tsentral'noi ta Skhidnoi Yevropy [Institutional Framework for Implementing Regional Policy in Central and Eastern Europe] Teoriia ta praktyka derzhavnoho upravlinnia - Theory and practice of public administration, 4(39), 460-467.

8. Heyts, V. M. (2016). Derzhavni tsil'ovi prohramy ta uporiadkuvannia prohramnoho protsesu $\mathrm{v}$ biudzhetnii sferi [State Target Programs and Programming Processes in the Budget Area] Kyiv: Naukova dumka [in Ukrainian].

9. Babaiev, V. M. (2017). Suchasni politychni praktyky krain Yevropy: dosvid dlia formuvannia rehional'noi polityky $\mathrm{v}$ Ukraini [Modern political practices of European countries: experience for the formation of regional policy in Ukraine ] Derzhavne budivnytstvo - State construction, 1,1 Retrieved from kbuapa.kharkov.ua/e-book/ db/2017-1-1/doc/5/01.pdf [in Ukrainian].

10. Kulenkova, O.Yu. (Ed.). European Principles of Public Administration (2016). Kyiv: Vyd-vo UADU.

11. Karpets', S.L. (2008). Svitovyi dosvid upravlinnia rehional'nym rozvytkom [World experience in managing regional development] Visnyk ZHDTU - Bulletin of the ZhDTU, 2(44), 252-258.

12. Zul'fuharova, S.O. (2015). Modeli upravlinnia ekonomichnym rozvytkom rehionu [Modeles of management of economic development of the region]. Extended abstract of candidate's thesis. Zaporizhzhia [in Ukrainian].

13. Pysarenko, S. (Eds.). (2016). Menedzhment yevropeys'koi ekonomichnoi intehratsii [Management of European Economic Integration] Kyiv, Znannya [in Ukrainian].

14. Prudnikova, L.O. (2016). Dosvid podolannia sotsial'noekonomichnykh dysproportsii rozvytku rehioniv zarubizhnykh krain [Experience of Overcoming Socio-Economic Disproportions in the Development of Regions of 
Foreign Countries] Ekonomichnyy visnyk Donbasu - Economic Bulletin of the Donbas, 3(21), 32-35 [in Ukrainian].

15. Yurmanova, Ye. A. (2016). Gosudarstvo blagosostoyaniia i sektor sotsial'noi ekonomiki: formirovaniie mekhanizma institutsional'nogo vzaimodeystviia [The welfare state and the social economy sector: the formation of the mechanism of institutional interaction]. Nauchnyye trudy DNTU. Seriya: ekonomicheskaya - Scientific works of the DNTU. Series: economic, 40-2, 205-212 [in Russian].

16. Chukhno, A. (2017). Instytutsionalizm: teoriia, metodolohiia, znachennia [Institutionalism: Theory, Methodology, Value]. Ekonomika Ukrayiny - Economy of Ukraine, 7, 4-12 [in Ukrainian].

17. Smentyna, N. V. (2015). Stratehichne planuvannia sotsial'noekonomichnoho rozvytku na mezorivni: teoriia, metodolohiyia, praktyka [Strategic Planning of Socio-Economic Development on Mesorite: Theory, Methodology, Practice]. Odesa: Atlant [in Ukrainian].

18. Pyroh, O.V. (2016). Stratehichni perspektyvy ekonomichnoho rozvytku natsional'noi ekonomiky Ukrainy [Strategic Prospects for Economic Development of the National Economy of Ukraine]. Biznes-inform - Businessinform, 11,32-34 [in Ukrainian].

19. Mirzodayeva, T.V. (2009). Zasady vyrivniuvannia terytorial'nykh dysproportsii $\mathrm{v}$ konteksti ekonomichnoii bezpeky rehioniv [Principles of equalizing territorial disproportions in the context of economic security of regions ] Ekonomichnyi prostir - Economic space, 21, 138-146 [in Ukrainian].

20. Mazur, H. F., \& Kovalenko, H. O. (2015). Pryntsypy prohnozuvannia sotsial'noekonomichnoho rozvytku rehionu [Principles of forecasting socioeconomic development of the region]. Uman' : UNUS [in Ukrainian].

21. Chuzhykov, V. (2015). Ches'ka model' rehional'noho rozvytku [Czech model of regional development]. Ekonomika Ukrayiny - Economy of Ukraine, 7, 72-78 [in Ukrainian]. 